\title{
Front Matter: Volume 6734
}

, "Front Matter: Volume 6734," Proc. SPIE 6734, International Conference on Lasers, Applications, and Technologies 2007: Laser Technologies for Medicine, 673401 (7 August 2007); doi: 10.1117/12.768442

SDIE Event: International Conference on Lasers, Applications, and Technologies '07, 2007, Minsk, Belarus 


\title{
PROGRESS IN BIOMEDICAL OPTICS AND IMAGING
}

Vol. 8, No. 38

\section{International Conference on Lasers, Applications, and Technologies 2007 Laser Technologies for Medicine}

\author{
Vladislav Panchenko \\ Andrey Larichev \\ George Zheltov \\ Editors
}

28 May-1 June 2007

Minsk, Belarus

Organized by

National Academy of Sciences (Belarus) - Russian Academy of Sciences - M.V. Lomonosov Moscow State University (Russia) • B.I. Stepanov Institute of Physics (Belarus) • International Science and Technologies Center

Sponsored by

National Academy of Sciences (Belarus) - Russian Academy of Sciences - M.V. Lomonosov Moscow State University (Russia) - Belarus Foundation for Basic Research • Belarus Physical Society • Russian Physical Society • International Science and Technologies Center • SPIE Russia Chapter

Published by

SPIE

Volume 6734 
The papers included in this volume were part of the technical conference cited on the cover and title page. Papers were selected and subject to review by the editors and conference program committee. Some conference presentations may not be available for publication. The papers published in these proceedings reflect the work and thoughts of the authors and are published herein as submitted. The publisher is not responsible for the validity of the information or for any outcomes resulting from reliance thereon.

Please use the following format to cite material from this book:

Author(s), "Title of Paper," in International Conference on Lasers, Applications, and Technologies 2007: Laser Technologies for Medicine, edited by Vladislav Panchenko, Andrey Larichev, George Zheltov, Proceedings of SPIE Vol. 6734 (SPIE, Bellingham, WA, 2007) Article CID Number.

ISSN 1605-7422

ISBN 9780819468925

Published by

SPIE

P.O. Box 10, Bellingham, Washington 98227-0010 USA

Telephone +1 3606763290 (Pacific Time) · Fax +1 3606471445

SPIE.org

Copyright (C) 2007, Society of Photo-Optical Instrumentation Engineers.

Copying of material in this book for internal or personal use, or for the internal or personal use of specific clients, beyond the fair use provisions granted by the U.S. Copyright Law is authorized by SPIE subject to payment of copying fees. The Transactional Reporting Service base fee for this volume is $\$ 18.00$ per article (or portion thereof), which should be paid directly to the Copyright Clearance Center (CCC), 222 Rosewood Drive, Danvers, MA 01923. Payment may also be made electronically through CCC Online at copyright.com. Other copying for republication, resale, advertising or promotion, or any form of systematic or multiple reproduction of any material in this book is prohibited except with permission in writing from the publisher. The CCC fee code is 1605 $7422 / 07 / \$ 18.00$.

Printed in the United States of America.

Publication of record for individual papers is online in the SPIE Digital Library.

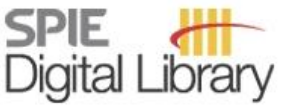

SPIEDigitallibrary.org

Paper Numbering: Proceedings of SPIE follow an e-First publication model, with papers published first online and then in print and on CD-ROM. Papers are published as they are submitted and meet publication criteria. A unique, consistent, permanent citation identifier (CID) number is assigned to each article at the time of the first publication. Utilization of CIDs allows articles to be fully citable as soon they are published online, and connects the same identifier to all online, print, and electronic versions of the publication. SPIE uses a six-digit CID article numbering system in which:

- The first four digits correspond to the SPIE volume number.

- The last two digits indicate publication order within the volume using a Base 36 numbering system employing both numerals and letters. These two-number sets start with 00, 01, 02, 03, 04 , $05,06,07,08,09,0 A, 0 B \ldots 0 Z$, followed by 10-1Z, 20-2Z, etc.

The CID number appears on each page of the manuscript. The complete citation is used on the first page, and an abbreviated version on subsequent pages. Numbers in the index correspond to the last two digits of the six-digit CID number. 


\section{Contents}

vii Conference Committee

ix Symposium Committee

\section{LASER TECHNOLOGIES FOR MEDICINE}

673404 Investigation of possibility of submillimeter laser using as instrument for diagnostics in medicine [6734-03]

V. I. Fedorov, A. G. Khamoyan, Institute of Laser Physics (Russia); E. Ya. Shevela,

E. R. Chernykh, Institute of Clinical Immunology (Russia)

673405 Optimum design of optical fiber bundles for medical imaging [6734-04]

J. L. Arce-Diego, F. Fanjul-Vélez, N. Ortega-Quijano, M. L. Pelayo-Fernández,

J. González-García, P. Zorrilla de la Fuente, Univ. of Cantabria (Spain)

673406 Laser optoacoustics as a tool for the diagnostics of the diluted biological and medical suspensions of micron-size and nano-size particles (Invited Paper) [6734-05]

S. V. Egerev, O. B. Ovchinnikov, A. V. Fokin, Andreyev Acoustics Institute (Russia)

673409 Localization of tissue pathological changes [6734-08]

A. R. Sindyaeva, V. P. Zakharov, Samara State Aerospace Univ. (Russia)

6734 OA Current and long-term technologies of laser therapy (Invited Paper) [6734-09]

V. S. Ulashcyk, Institute of Physiology (Belarus); A. V. Volotovskaya, Belarusian Medical

Academy of Post Graduate Education (Belarus)

6734 OE Nanocluster: photothermal bubble as optical probes for cytometric and microscopic applications [6734-13]

D. O. Lapotko, E. Y. Lukianova-Hleb, Lykov Heat and Mass Transfer Institute (Belarus);

J. H. Hafner, Rice Univ. (USA)

$6734 \mathrm{OH}$ Prostate cancer detection by laser induced autofluorescence and multicomponent spectroscopy [6734-16]

G. Salomon, T. Hess, A. Erbersdobler, C. Eichelberg, Univ. Hospital Hamburg-Eppendorf (Germany); S. Greschner, Fraunhofer Institute for Nondestructive Testing (Germany); A. N. Sobchuk, B.I. Stepanov Institute of Physics (Belarus); A. K. Korolik, Belorussian State Medical Univ. (Belarus); N. A. Nemkovich, B.I. Stepanov Institute of Physics (Belarus); J. Schreiber, M. Herms, Fraunhofer Institute for Nondestructive Testing (Germany); M. Graefen, Martini Clinic, Prostate Cancer Ctr. (Germany); H. Huland, Univ. Hospital Hamburg-Eppendorf (Germany) and Martini Clinic, Prostate Cancer Ctr. (Germany)

$6734 \mathrm{O}$ Optical properties of human stomach mucosa in the spectral range from 400 to $2000 \mathrm{~nm}$ [6734-17]

A. N. Bashkatov, E. A. Genina, V. I. Kochubey, A. A. Gavrilova, Saratov State Univ. (Russia); S. V. Kapralov, V. A. Grishaev, Saratov State Medical Univ. (Russia); V. V. Tuchin, Saratov State Univ. (Russia) 
6734 OK Diffuse fluorescence tomography of exo- and endogenously labeled tumors [6734-19] I. V. Balalaeva, Institute of Applied Physics (Russia) and Nizhny Novgorod State Univ. (Russia); I. V. Turchin, A. G. Orlova, V. I. Plekhanov, Institute of Applied Physics (Russia); M. V. Shirmanova, Nizhny Novgorod State Univ. (Russia) and Institute of Fundamental and Applied Medicine (Russia); M. S. Kleshnin, I. I. Fiks, Institute of Applied Physics (Russia); E. V. Zagainova, Institute of Fundamental and Applied Medicine (Russia); V. A. Kamensky, Institute of Applied Physics (Russia)

$6734 \mathrm{ON}$ Porous surface structure of biocompatible implants and tissue scaffolds base of titanium and nitinol synthesized SLS/M method [6734-22]

I. Shishkovsky, V. Sherbakov, A. Petriv, P.N. Lebedev Physics Institute (Russia); M. Kuznetsov, Yu. Morozov, Institute of Problems of Chemical Physics (Russia); L. Volova, I. Barikov,

S. Fakeev, Samara State Medical Univ. (Russia)

673400 High beam quality and high power $\mathrm{CO}_{2}$ lasers for technologies and medicine [6734-23] V. V. Vasiltsov, Institute on Laser and Information Technologies (Russia); I. I. Berishvili, A.N. Bakoulev Cardiovascular Scientific Ctr. (Russia); M. G. Galushkin, V. S. Golubev, V. Ya. Panchenko, V. A. Ulyanov, N. N. Zinina, Institute on Laser and Information Technologies (Russia); M. N. Vakhromeeva, A. Y. Vakhrameeva, A.N. Bakoulev Cardiovascular Scientific Ctr. (Russia)

$6734 \mathrm{OQ}$ Manipulation of blood parameters in the skin by the low-power laser irradiation [6734-25] A. N. Korolevich, Institute of Physics (Belarus) and Minho Univ. (Portugal); E. K. Naumenko, Institute of Physics (Belarus); N. S. Dubina, S. I. Vecherinsky, GP MTZ Medservice (Belarus); M. Belsley, Minho Univ. (Portugal)

6734 OS Laser-optical method of visualization the local net of tissue blood vessels and its biomedical applications [6734-27]

M. M. Asimov, Institute of Physics (Belarus); R. M. Asimov, Applied Systems Ltd. (Belarus); A. N. Rubinov, Institute of Physics (Belarus)

6734 OY Ablation algorithms and corneal asphericity in myopic correction with excimer lasers [6734-33]

N. G. Iroshnikov, A. V. Larichev, Moscow State Univ. (Russia); M. G. Yablokov, S.N. Fedorov Eye Microsurgery State Institution (Russia)

$67340 Z$ Phototechnologies for fabrication of bifocal intraocular lenses [6734-34]

V. P. Koronkevich, V. P. Korolkov, G. A. Lenkova, Institute of Automation and Electrometry (Russia); V. M. Treushnikov, E. A. Viktorova, Scientific production enterprise Reper-NN (Russia); I. A. Iskakov, FGU MNTK Eye Microsurgery (Russia); A. S. Gutman, Joint-Stock Company IntraOL (Russia)

673415 Fluorescence and reflectance properties of hemoglobin-pigmented skin disorders [6734-40]

P. Troyanova, National Oncological Ctr. (Bulgaria); E. Borisova, L. Avramov, Institute of Electronics (Bulgaria)

673416 Influence of measurement geometry on the human skin reflectance spectra detection [6734-41]

E. Borisova, Institute of Electronics (Bulgaria); P. Troyanova, National Oncological

Diagnostic Ctr. (Bulgaria); L. Avramov, Institute of Electronics (Bulgaria) 
673417 Retrieval of particle characteristics with high-order neural networks: application to scanning flow cytometry [6734-42]

V. V. Berdnik, Institute of Aerospace Device-Making (Russia); V. A. Loiko, B.I. Stepanov Institute of Physics (Belarus)

673419 Skin optical clearing for improvement of laser tattoo removal [6734-44]

E. A. Genina, A. N. Bashkatov, A. A. Gavrilova, A. B. Pravdin, V. V. Tuchin, Saratov State Univ. (Russia); I. V. Yaroslavsky, G. B. Altshuler, Palomar Medical Products (USA)

6734 1A Regulation of medicine bioavailability by laser radiation action [6734-45]

A. Lisenkova, T. Zheleznyakova, V. Lavrova, V. Sentchouk, Belarusian State Univ. (Belarus)

6734 IB Application of laser therapy in the treatment of brain ischemia [6734-46]

G. A. Zalesskaya, Institute of Molecular and Atomic Physics (Belarus); N. I. Nechipurenko, J. I. Musienko, A. V. Kuchinsky, Institute of Neurology, Neurosurgery, and Physiotherapy (Belarus)

6734 1C Development of human granulocyte morphometric model for scanning flow cytometry [6734-47]

G. I. Ruban, Stepanov Institute of Physics (Belarus); S. M. Kosmacheva, N. V. Goncharova, Ctr. of Hematology and Transfusiology (Belarus); V. A. Loiko, Stepanov Institute of Physics (Belarus)

6734 ID Photodynamic therapy of rat alveolar hepatic cancer (RS-1) with application and phonophoresis of Fotolon ointment [6734-48]

N. A. Popova, Belarusian Medical Academy of Post-Graduate Education (Belarus)

6734 IF A comparative analysis of photoinduced tumors necrosis with/without a photosensitizer [6734-50]

S. A. Biziuk, B. M. Dzhagarov, Institute of Molecular and Atomic Physics (Belarus);

Y. P. Istomin, N.N. Alexandrov Research Institute of Oncology and Medical Radiology

(Belarus); M. V. Parkhats, Institute of Molecular and Atomic Physics (Belarus)

6734 1H 2D Mueller matrix approach for tissue complete polarization characterization [6734-52] F. Fanjul-Vélez, J. L. Arce-Diego, Univ. of Cantabria (Spain); O. G. Romanov, A. L. Tolstik, O. Ormachea, Belarusian State Univ. (Belarus)

$67341 \mathrm{M}$ Laser coagulation of tissues by $1,6 \boldsymbol{\mu m}$ and $\mathbf{2} \boldsymbol{\mu m}$ laser radiation [6734-57]

L. E. Batay, D. N. Busko, A. I. Vodchits, S. V. Voitikov, V. A. Orlovich, B.I. Stepanov Institute of Physics (Belarus); V. S. Ulastchik, N. B. Gorbunova, V. A. Kulchitskii, Institute of Physiology (Belarus)

6734 IP Evaluation of multilayer tissues in optical coherence tomography by the extended Kalman filtering method [6734-60]

I. Gurov, M. Volynsky, A. Zakharov, St. Petersburg State Univ. of Information Technologies, Mechanics and Optics (Russia) 
6734 IR Influence of laser irradiation on superoxide dismutase activity of human lymphocytes in vitro [6734-62]

A. V. Volotovskaya, Belarusian Medical Academy of Post Graduate Education (Belarus); N. M. Kozlova, A. N. Antonovich, E. I. Slobozhanina, Institute of Biophysics and Cell Engineering (Belarus)

6734 is Laser fluorescent method for differential diagnostics of cataract [6734-63]

V. V. Salmin, A. S. Provorov, Siberian Federal Univ. (Russia); V. I. Lazarenko, A. B. Salmina, S. A. Oskirko, Krasnoyarsk State Medical Academy (Russia); D. S. Fokina, E. S. Vladimirova, Siberian Federal Univ. (Russia)

$6734 \mathrm{IT} \mathrm{HbCO}$ photodissociation at the photolysing radiation wavelength range $550-585 \mathrm{~nm}$ [6734-64]

V. V. Kuzmin, V. V. Salmin, Siberian Federal Univ. (Russia); A. B. Salmina, Krasnoyarsk State Medical Academy (Russia); A. S. Provorov, Siberian Federal Univ. (Russia)

6734 IV Specialized modal tomography of human eye aberrations [6734-66]

A. S. Goncharov, A. V. Larichev, M.V. Lomonosov Moscow State Univ. (Russia)

6734 1X Peculiarities of laser lithotripsy using a microsecond laser [6734-68]

V. Tarkovsky, S. Anufrik, Yanka Kupala State Univ. of Grodno (Belarus)

Author Index 


\title{
Conference Committee
}

\author{
LAT 2007 Program Committee Chairs
}

Vladislav Panchenko, Institute on Laser and Information Technologies (Russia)

Valentin A. Orlovich, B.I. Stepanov Institute of Physics (Belarus)

LAT 2007 Scientific Secretaries

Mikhail Khodasevich, B.I. Stepanov Institute of Physics (Belarus)

Tatiana Lukovnikova, Institute on Laser and Information Technologies (Russia)

Conference Chairs

Andrey V. Larichev, M.V. Lomonosov Moscow State University (Russia) George Zheltov, B.I. Stepanov Institute of Physics (Belarus)

Program Committee

Vasiliy Mostovnikov, B.I. Stepanov Institute of Physics (Belarus)

Lev Perlman, Harvard University (USA)

Aleksey Shkadarevich, Republican Enterprise Lasers in Ecology, Medicine, and Technology (Belarus)

Emil Sobol, Institute on Laser and Information Technologies (Russia)

Pierre-Yves Turpin, University Pierre and Marie Curie (France)

Vladimir S. Ulashchyk, Institute of Physiology (Belarus)

Toyohiko Yatagai, University of Tsukuba (Japan)

Boris Zubov, General Physics Institute (Russia) 
Downloaded From: https://www.spiedigitallibrary.org/conference-proceedings-of-spie on 26 Apr 2023

Terms of Use: https://www.spiedigitallibrary.org/terms-of-use 


\title{
Symposium Committees
}

\author{
ICONO/LAT 2007 General Chairs
}

Sergey N. Bagayev, Institute of Laser Physics (Russia)

Anatoly Rubinov, B.I. Stepanov Institute of Physics (Belarus)

ICONO/LAT 2007 General Vice-Chairs

Nikolai Kazak, B.I. Stepanov Institute of Physics (Belarus)

Vladimir Makarov, M.V. Lomonosov Moscow State University

(Russia)

ICONO/LAT 2007 Organizing Committee

Committee Chair

Vladimir Kabanov, B.I. Stepanov Institute of Physics (Belarus)

Committee Vice-Chairs

Vitaly Plavski, B.I. Stepanov Institute of Physics (Belarus)

Pavel Mikheev, M.V. Lomonosov Moscow State University (Russia)

Committee Members

Maria Drabovich, M.V. Lomonosov Moscow State University (Russia)

Alexander Grabchikov, B.I. Stepanov Institute of Physics (Belarus)

Valeri Gudelev, B.I. Stepanov Institute of Physics (Belarus)

Vyacheslav Dlugunovich, B.I. Stepanov Institute of Physics (Belarus)

Eugene Ivakin, B.I. Stepanov Institute of Physics (Belarus)

Maria Kulagina, B.I. Stepanov Institute of Physics (Belarus)

Boris Kuntsevich, B.I. Stepanov Institute of Physics (Belarus)

Svetlana Kurilkina, B.I. Stepanov Institute of Physics (Belarus)

Galina Ledneva, B.I. Stepanov Institute of Physics (Belarus)

Eugene Lutsenko, B.I. Stepanov Institute of Physics (Belarus)

Nikolai Malevich, B.I. Stepanov Institute of Physics (Belarus)

Andrey Olenin, M.V. Lomonosov Moscow State University (Russia)

Valeri Pavlenko, B.I. Stepanov Institute of Physics (Belarus)

Vyacheslav Pavlovskii, B.I. Stepanov Institute of Physics (Belarus)

Gennadi Ryabtsev, B.I. Stepanov Institute of Physics (Belarus)

Andrey N. Sobchuk, B.I. Stepanov Institute of Physics (Belarus)

Antonina Tretyakova, B.I. Stepanov Institute of Physics (Belarus)

Vyachedslav Chizhevskii, B.I. Stepanov Institute of Physics (Belarus)

Roman Shulyakovski, B.I. Stepanov Institute of Physics (Belarus) 
Downloaded From: https://www.spiedigitallibrary.org/conference-proceedings-of-spie on 26 Apr 2023

Terms of Use: https://www.spiedigitallibrary.org/terms-of-use 